\title{
STUDY THE HARMFUL EFFECTS OF SODIUM METABISULFITE ON LIVER, TESTES, AND LIPID PEROXIDATION IN MALE MICE, (MUS MUSCULUS)
}

\author{
Irum Naureen \\ (Assistant professor) \\ School of zoology Minhaj University Lahore Pakistan \\ Aisha Saleem, Attique Nawaz, Mahnoor Javed \\ (M.phil researcher) \\ School of zoology Minhaj University Lahore Pakistan
}

\begin{abstract}
:
Purpose - The present study was designed to evaluate the toxic effect of Sodium metabisulfite (SMB) on testes and liver of 8 week- old mouse, which were grouped as control (C) and dose group, SM $(500 \mathrm{mg} / \mathrm{kg} \quad$ B.W SMB $)$. The Experimental group was injected 0.1ml SM (500 $\mathrm{mg} / \mathrm{g} \mathrm{B.W}+10 \mathrm{ml}$ distilled water) for twenty-one days, while a control group was given $0.1 \mathrm{ml}$ water for the same durations. Recovered testes were subjected to morphological, morphometric, and histological analysis. A Hormone evaluation was also conducted. Methods Dose group SM (500 $\mathrm{mg} / \mathrm{kg}$ B.W SMB) showed morphological defects like wrinkles on the surface, shrinkage, small size, whereas the testes of control group appeared normal just like control (C). Morphometric analysis of dose group SM (500 mg/g B.W SMB) showed significant decrease in length, width and weight of testis as compared to control group. Blood analysis showed significantly levels of testosterone and glutathione reductions in dose group SM (500 mg/g B.W SMB) as compared to the control group. While the level of Melanodialdehyde (MDA) increased significantly in dose group SM $(500 \mathrm{mg} / \mathrm{g}$ B.W SMB $)$ as compare to the control group. Histological defects were observed in testes of dose group SM $(500$ $\mathrm{mg} / \mathrm{g}$ B.W SMB) like deshaped somniferous tubule, degenerated spermatids, vacuolization, rupturing of germinal epithelium, absence of sperms in the lumen, degenerated peritubular myoid cells, hyalinization, cluster of degenerated spermatozoa in lumen and absence of leydig cells. Histology of the liver showed various defects like
\end{abstract}

mitotic cells, vacuolization, degeneration of hepatic cells and cell shrinkage, broad suicidal spacing, absence of bile canaliculus cells, regenerated kuppfer cell, and interrupted sheet of hepatocytes. Conclusion - The harmful impact of sodium metabisulfite on the liver and reproductive system of male mice. A Sharp decrease in the level of testosterone was formed to be a key factor for studied deformation in morphology, morphometry, and histology oftestes. Sodium metabisulfite-induced deformities were also indicated in the liver tissue due to a significant decrease in glutathione and an increase in MDA (Malondialdehyde) level. Hence it is strongly recommended to reduce the use of sodium metabisulfite in our daily use products as it's not only harmful to mice but also for men.

Key words: Sodium metabisulfite, Testes, liver, male mice (Mus musculus) haematology, physiology.

\section{INTRODUCTION}

Sodium metabisulfite (SM) is a white translucent or powder strong substance with a slight sulfur scent and this compound turns into a destructive corrosive when they are blended in with water. As they become a destructive corrosive, SM can cause hack and wheezing when breathed in. SM happens because of the impacts of sulfur dioxide, which influences the tangible nerves and causes arbiter discharge. Sodium metabisulfite is a broadly utilized biocide, usually as an additive in food handling and customer items.

Sulfites are added as additives to an assortment of nutrition in different types of food items e.g. bread 


\section{International Journal of Engineering Applied Sciences and Technology, 2021 \\ Vol. 6, Issue 5, ISSN No. 2455-2143, Pages 30-38 \\ Published Online September 2021 in IJEAST (http://www.ijeast.com)}

rolls, chocolate, jam, brew, wine, and so forth and in prescriptions, like parenteral amino corrosive arrangements. Sulfite salts are part of different chemicals like sodium metabisulfite(SMB), potassium metabisulfite(KMB), sodium bisulfate, potassium sulfite, and sodium sulfite and are perceived as "sulfating specialists" since they discharge sulfur dioxide ${ }^{(\mathbf{1})}$. Sulfites impacts poisonous impacts on the regenerative framework, the respiratory framework, and the sensory system and can likewise prompt hypersensitive responses. Sodium metabisulfite (SM) is a white glasslike or powder strong concoction with a slight sulfur scent and this compound turns into a destructive corrosive when they are blended in with water. As they become a destructive corrosive, SM can cause hack and wheezing when breathed in. ${ }^{(3)}$ Sodium metabisulfite reduces testosterone, an abatement of $68 \%$.Testosterone is an essential germ cell perseverance element since it elimination prompts germ cell apoptosis and it is fundamental keeping up spermatogenesis and male readiness. ${ }^{(2)}$

Sodiummetabisulfite are the quantitative auxiliary parts of the gonad. Besides, it intends to present a defensive operator that could be effectively overcome with the least antagonistic impacts. In the body, lipid emulsions are cleared from the blood dependent on their physicochemical properties and the physiological reaction of the reticuloendothelial framework. ${ }^{(4)}$ Sulfite is essentially scattered to all body tissues, including the central system (CNS), by being invested in the stomach. ${ }^{(3)}$ The liver and kidney show high range of sulfite, while gonad shows low sulfite oxidase exercises. ${ }^{(\mathbf{5})}$ Theimpacts of sulfating specialists of these structures on the brain, while hardly any investigations have been distributed on these consequences for the gonad. ${ }^{(4)}$

\section{STUDY DESIGN AND METHODOLOGY:}

This study is an experimental study.

A group of 30 male mice (Mus musculus) were placed under the diverse controlled conditions, e.g., 12 hour day/night cycle, $27 \pm 2^{\circ} \mathrm{C}$ temperatures with 40-50\% \%umidity rates. These were kept in iron cages having a size of 24 inches in length and 12 inches wide. The most available feed named Chick feed No.14, richly supplied with minerals, proteins, and multivitamins were given to mice. The Control group was labeled as (C), while the experimental group was labeled as SM. The Dose was prepared on 500 $\mathrm{mg} / \mathrm{kg}$ B.W of SMB was dissolved in $10 \mathrm{ml}$ of distilled water in such a way that every $0.1 \mathrm{ml}$ contained the desired $(500 \mathrm{mg} / \mathrm{kg})$ concentration of the required dose. The Dose was given intraperitoneally to mice with the help of an insulin syringe.

\section{HORMONE MEASUREMENT:}

Blood samples were directly collected from the hearts of male mice to estimate various analyses in the body. 1) Testosterone: A Radio immune assay (RIA) was used to measure the blood testosterone level.

2) Glutathione peroxidase 5(GPx5): The GPx 5 was assessed by the advancement RIA (radioimmunoassay). This advancement uses two high proclivity monoclonal antibodies.

3) Malondialdehyde (MDA): MDA esteem was also evaluated by following the protocol of Ohkawa et al. (1979). The tissue test was $200 \mathrm{ul}$, and $8.1 \%$ sodium dodecyl sulfate (SDS), $1.5 \mathrm{~mL}$ of $20 \%$ acidic damaging game plan $(\mathrm{pH} 3.5)$. The mix was made up to $4.0 \mathrm{~mL}$ with refined water and warmed in a water shower at $90^{\circ} \mathrm{C}$ for $60 \mathrm{~min}$. Subsequent to cooling with fixture water $1.0 \mathrm{~mL}$ of refined water and $0.5 \mathrm{~mL}$ of n-butanol were added and shaken enthusiastically and centrifuged at $4000 \mathrm{rpm}$ for $10 \mathrm{~min}$. The upper butanol layer was taken and its absorbance at $532 \mathrm{~nm}$ was analyzed.

\section{SURGICAL INCISION / TISSUE SAMPLING:}

After the extraction of blood, testicles were removed for additional analysis. Mice were given anesthesia. By giving careful incision, testicles and liver were removed from the body. These organs were moved to saline for additional procedure. Tissue Sampling and Processing, after dismemberment, balls of each creature were set in Petri dish containing 0.9\% saline. The balls were then situated in Bouin's fixative for preservation. Testes were seen under a binocular stereoscopic magnifying lens and morphological abnormalities were noted. By then these bent gonads were small caught with the assistance of advanced camera.

\section{MORPHOMETRIC ANALYSIS:}

Computerized Vernier caliper was used to choose the length and width of testes of control and experimental groups. Advanced weight assessing balance was used to decide the heaps of each group 


\section{International Journal of Engineering Applied Sciences and Technology, 2021 \\ Vol. 6, Issue 5, ISSN No. 2455-2143, Pages 30-38 \\ Published Online September 2021 in IJEAST (http://www.ijeast.com)}

of testes. Morphometric anomalies were seen among control and experimental groups

\section{HISTOLOGICAL INVESTIGATION / DIGITALPHOTOGRAPHY:}

Analysis of the testicles include in each group. There were the various steps, which included lack of hydration by adopting particular categories of liquor, clearing and embedding in paraffin wax. The embedded tissues were transitionally segmented at $6-7 \mu \mathrm{m}$ at microtome. The consecutive segments were strained out on neat slides which covered with egg whites. At that point slides were recolored withHematoxylin. Histological slides after micro photographed were handled in adobe photograph examine for the change of sharpness and difference in shading alongside resizing utilizing advanced trimming, snaps making with arrows and star just as background change.

\section{STATISTICS:}

Information was inspected through the unpaired $\mathrm{T}$ test. A probability level of $p<0.001$ was assessed vast.

\section{RESULTS:}

The morphological assessment of control and the trial bunches were broke down. The morphological deformities initiated by sodium metabisulfite. The control group demonstrated typical type of the testicles. Testicles outer looked sparkly and smooth and gave off an impression of being a bigger and heavier. Their tones were smooth in appearance. (Fig, 1.1, 1.2, 1.3, 1.4,) ExperimentalGroup:Dose Group SM (500 mg/kg B.W SMB):Various variations from the norm showed up after morphological assessment of experimental group. Testicles got from the dose group SM $(500 \mathrm{mg} / \mathrm{kg} \mathrm{B.W} \mathrm{SMB})$ were the irregular and demonstrated shrinkage and wrinkles on their surface.

These are of little size and deshaped just when contrasted with the control.

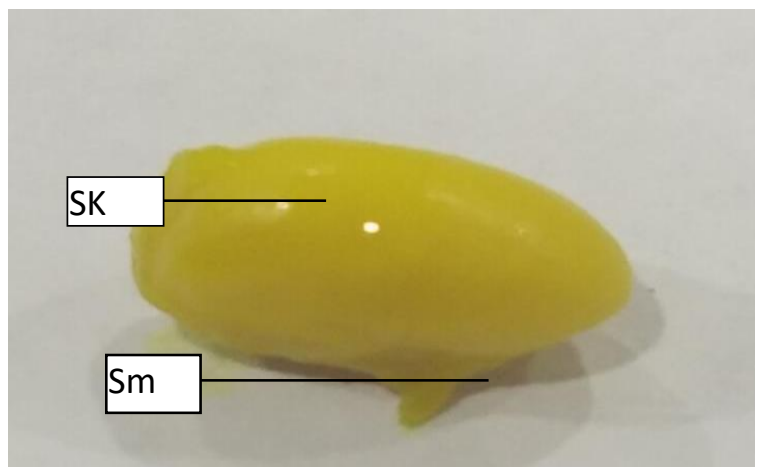

Fig 1.1: Macro photograph of testes of 8 week-old mouse of control group (C)SK: shrinkage, SK: shrinkage, Wr: wrinkle

S.s: small size:

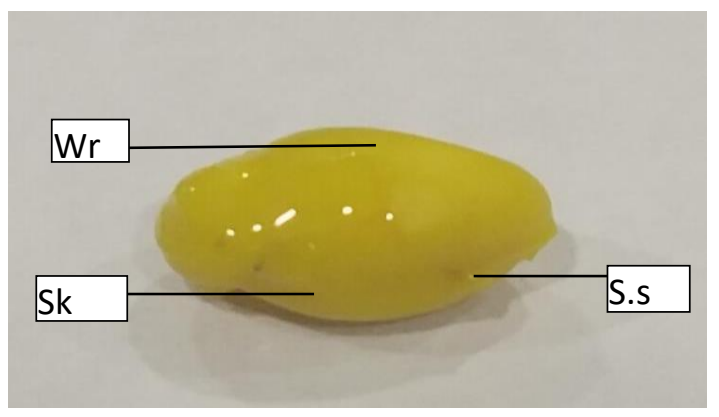

Figure 1.2: Macro photograph of testes of 8 weekold

mouse of control group (C) Wr: wrinkle, SK: shrinkage, S.s: small size

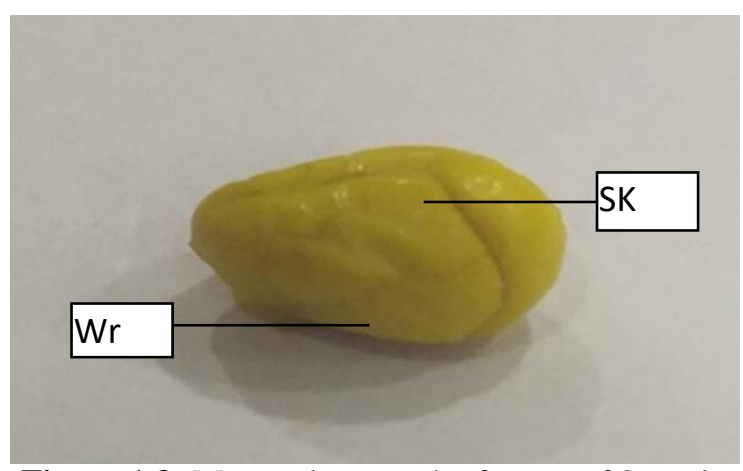

Figure 1.3: Macro photograph of testes of 8 weekold mouse of dose group SM (500mg/kgB.W) SK: shrinkage,

Wr: wrinkle, Ds: deshaped 


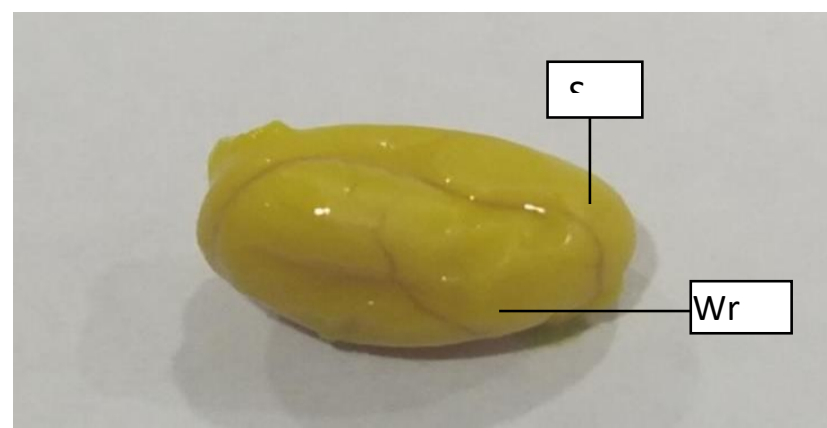

Figure: 1.4: Macro photograph of testes of 8 weekold mouse of dose group SM (500 mg/kg B.W) Length:

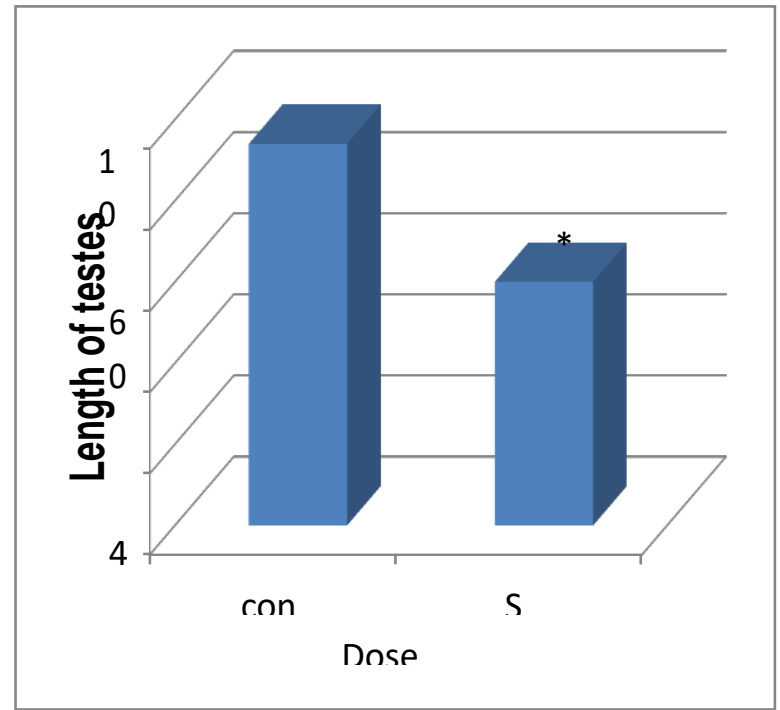

Fig: 1.5 Histogram indicating the impact of Sodium metabisulfite on the length of testicles of 8 week-old mouse.

\section{Width:}

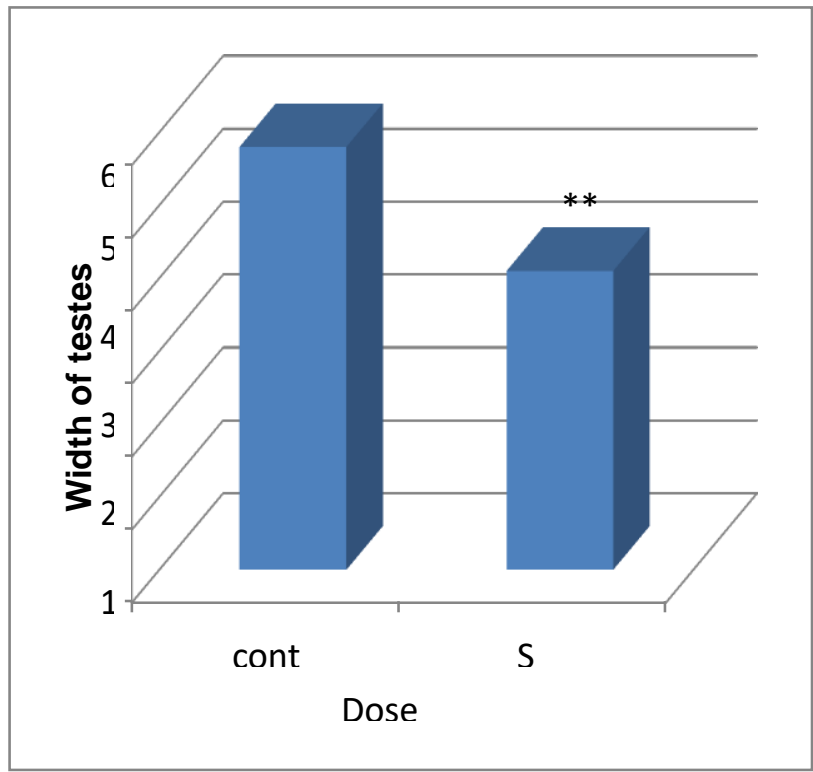

Fig: 1.6 Histogram indicating the impact of Sodium metabisulfite on the length of testicles of 8 week-old mouse.

Weight:

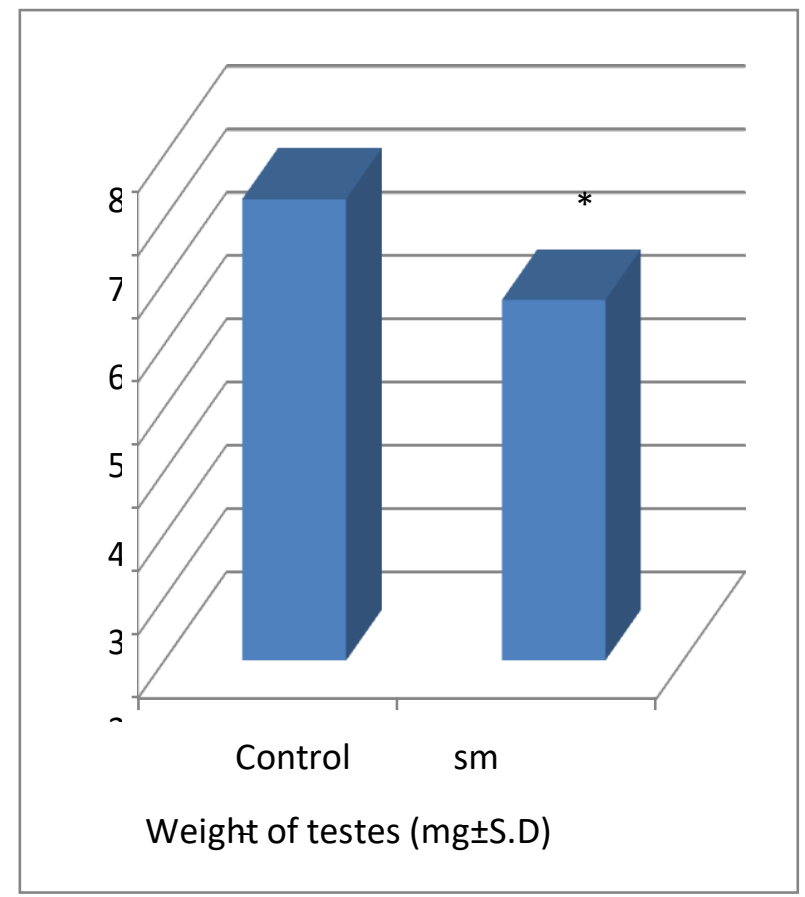

Fig: 1.7 Histogram indicating the impact of Sodium metabisulfite on the weight of testicles of 8 week-old mouse. Asterisks decides vast distinction against $* * *=$ $\mathrm{p}<0.001$

Table: 1 Impacts of dose of Sodium metabisulfite on length, width and weight of testicles of 8 week-old mouse.

\begin{tabular}{|c|l|l|l|}
\hline $\begin{array}{l}\text { Dose } \\
\text { group }\end{array}$ & $\begin{array}{l}\text { Normal length } \\
\text { of Testes } \\
(\mathbf{m m} \pm \text { S.D) }\end{array}$ & $\begin{array}{l}\text { Normal } \\
\text { width of } \\
\text { Testes } \\
(\mathbf{m m} \pm \\
\text { S.D) }\end{array}$ & $\begin{array}{l}\text { Weight of } \\
\text { Testes } \\
(\mathbf{m g} \pm \text { S.D })\end{array}$ \\
\hline Control & $7.3 \pm 0.1$ & $5.8 \pm 0.5$ & $94 \pm 5.4$ \\
\hline SM & $\begin{array}{l}* * * \\
5.7 \pm 0.5\end{array}$ & $\begin{array}{l}* * * \\
4.1 \pm 0.1\end{array}$ & $\begin{array}{c}* * * \\
60 \pm 7.07\end{array}$ \\
\hline
\end{tabular}


Table: 2 Impact of Sodium metabisulfite on blood testosterone level, Glutathione and Malondealdehyde (MDA) level in 8 week-old mouse.

Asterisks determines significant difference against $* * *=p<0.001$

\begin{tabular}{|c|c|c|c|}
\hline Dose group & $\begin{array}{l}\text { Level of } \\
\text { Testosterone } \\
(\mathrm{ng} / \mathrm{ml} \pm \text { S.D) }\end{array}$ & $\begin{array}{l}\text { Level of } \\
\text { Glutathione } \\
(\mathrm{mg} / \mathrm{dl} \pm \mathrm{S} . \mathrm{D})\end{array}$ & $\begin{array}{l}\text { Level of MDA } \\
(\mu \mathrm{mol} / \mathrm{ml} \pm \text { S.D })\end{array}$ \\
\hline Control & $7.40 \pm 0.008$ & $4.21 \pm 0.01$ & $0.8928 \pm 0.1$ \\
\hline SM & $\begin{array}{l}* * * \\
2.3 \pm 0.4\end{array}$ & $\begin{array}{l}* * * * \\
3.04 \pm \\
0.09\end{array}$ & $\begin{array}{ll}* * * & 1.30 \pm .1\end{array}$ \\
\hline
\end{tabular}

\section{Testosterone:}

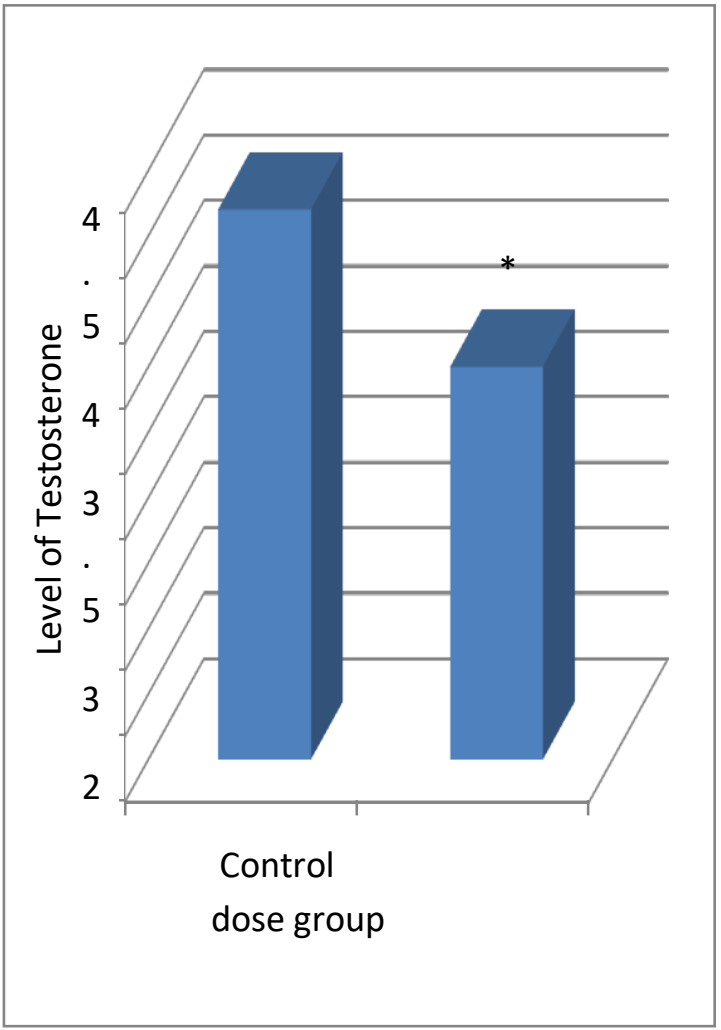

Fig: 1.8 Histogram demonstrating the impacts of Sodium metabisulfite on testosterone level in 8 weekold mouse. Critical distinction against ${ }^{* * *}=\mathrm{p}<0.001$

\section{Glutathione:}

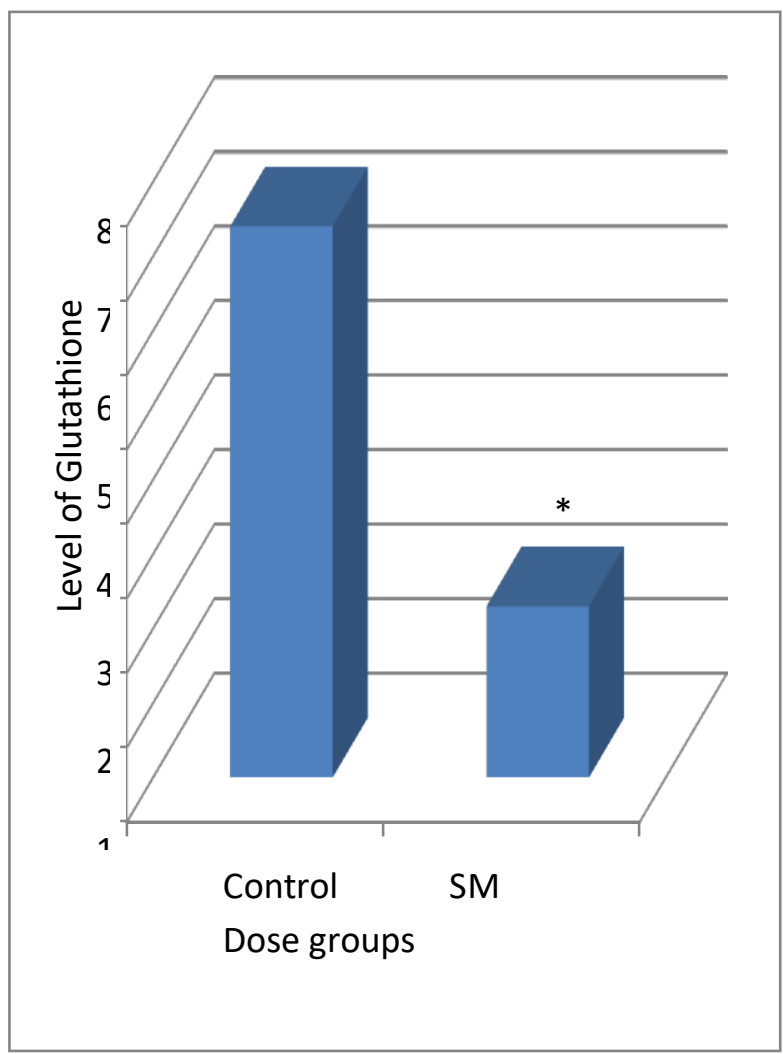

Fig: 1.9 Histogram demonstrating the impacts of Sodium metabisulfite on glutathione level in multi week-old mouse. Critical distinction against ${ }^{* * *}=\mathrm{p}<$ 0.001

Malondealdehyde (MDA):

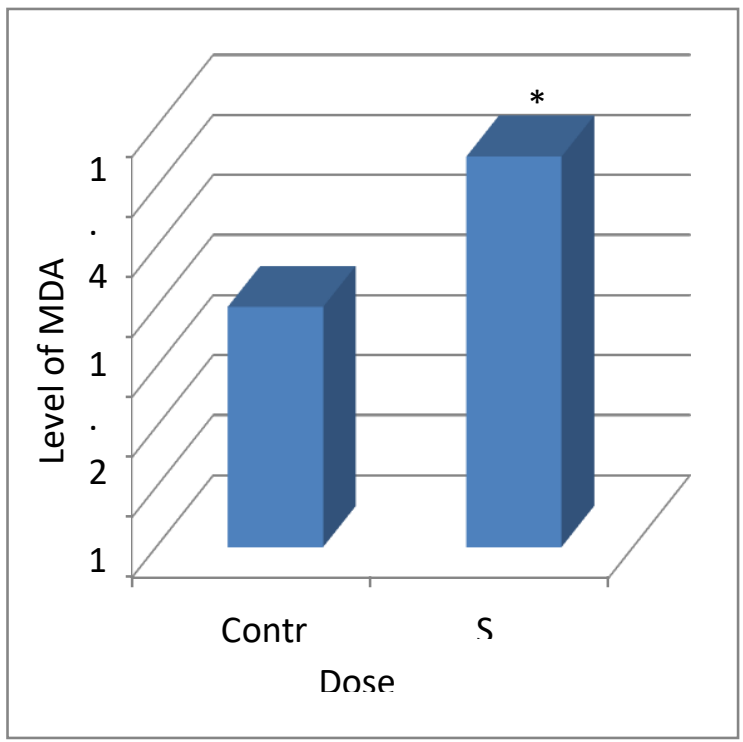




\section{International Journal of Engineering Applied Sciences and Technology, 2021 \\ Vol. 6, Issue 5, ISSN No. 2455-2143, Pages 30-38 \\ Published Online September 2021 in IJEAST (http://www.ijeast.com)}

Fig: 1.10 Histogram indicating the impacts of Sodium metabisulfite on Malondealdehyde (MDA) level in 8 week-old mouse. Critical distinction

$$
\text { against } * * *=p<0.001
$$

\section{Histological Analysis of Testes:}

\section{Control group:}

In the histological examination of control group, histopathologically irregularities were not found. The Control group of testes exhibited the ordinary appearance and plan of seminiferous tubules like, round formed seminiferous tubules were seen, which obviously showed sertoli cells, spermatogonia and create spermatozoa. A layer of peritubular myoid cells (smooth muscle) was found around the seminiferous tubules, reserved by connective tissues and interstitial Leydig cells (Fig: 2.1).

\section{Dose group SM (500 mg/kg B.W SMB):}

In dose group SM $(500 \mathrm{mg} / \mathrm{kg}$ B.W SMB $)$ certain segments epithelium layer was split which is also noted. Degeneration of interstitial cells and tubular malformation of seminiferous tubules were noted in some section as well. Histological deformities were observed in the form of tubular shape seminiferous tubules and decay of interstitial cells. In the specific sections less number of a sperm and spermatids were seen. Degenerated connective tissue and Leydig cells were also originate around the tubules heaving vacuoles. Other defects observed were desquamation of germinal epithelium, desquamated (Fig: 2.2 and 2.3)

\section{Experimental Group:}

In the histological analysis distinct abnormality were found in experimental group (Fig: 2.4 and 2.5)

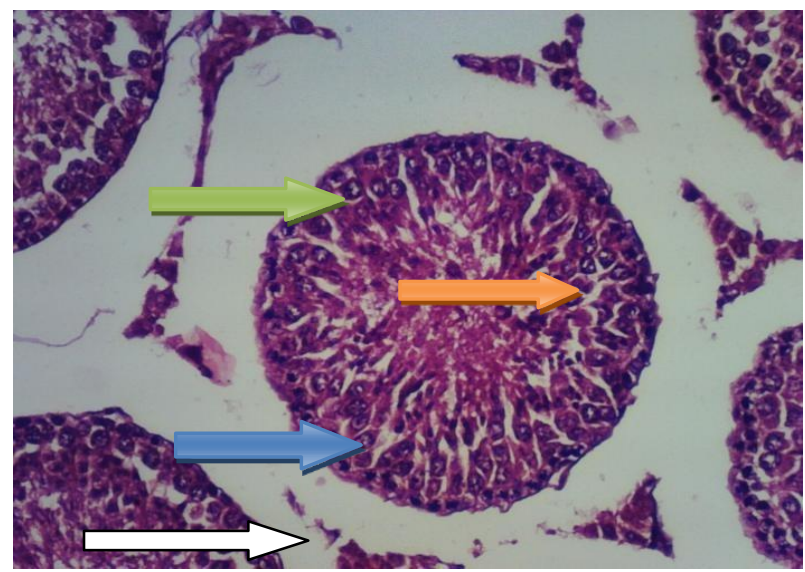

Fig: 2.1Transverse segment of testicular tissue of 8 week-old mouse of control group (C). Orange arrow: lumen, Green arrow: spermetocytes, Blue arrow: leydig cells. White arrows: Myoid cells.

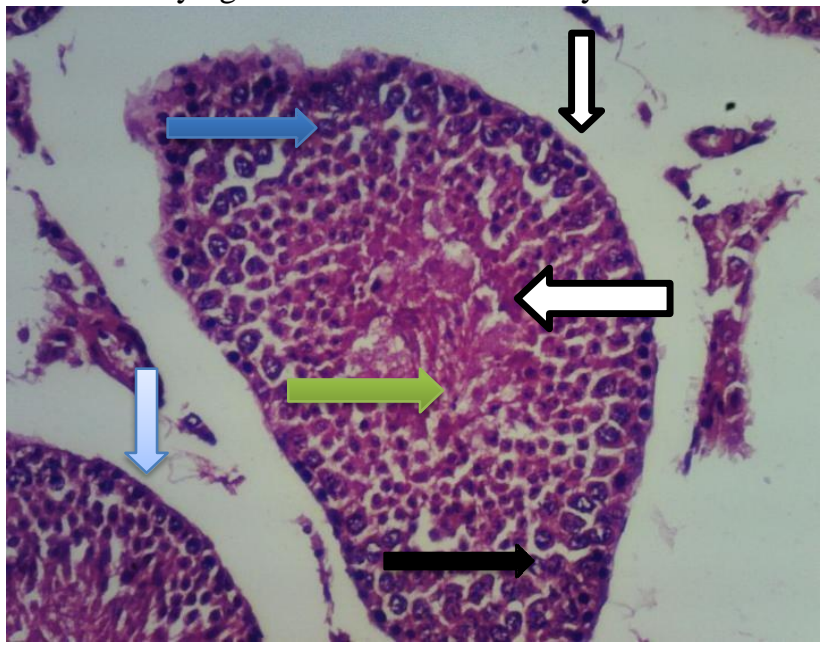

Fig: 2.2Transverse segment of testicular tissue of 8 week-old mouse of dose group SM $(500 \mathrm{mg} / \mathbf{k g}$ B.W SMB).

Green arrow: degeneration of spermatids, Blue arrow: Leydig cells White arrow: reduced lumen with aspermia, Black arrow: sertoli cells Narrow

white arrows: Desquamated cells from basal membrane Light blue arrow: Hyalinization

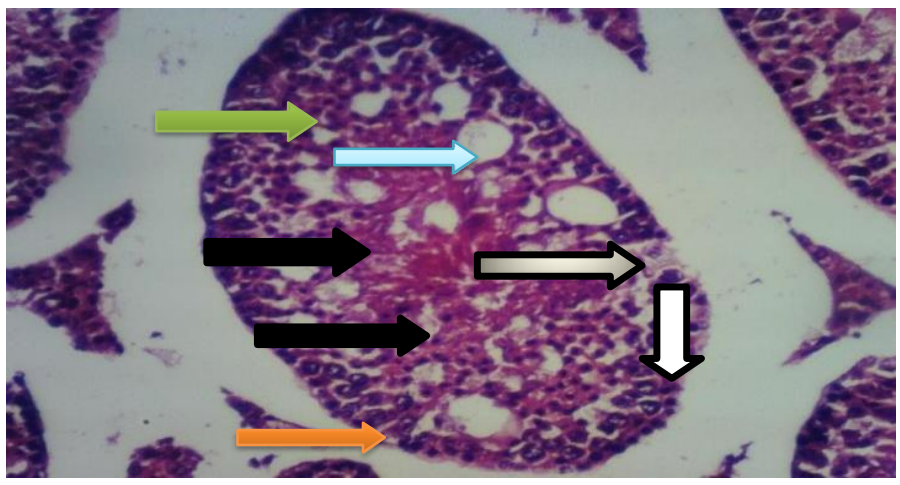

Fig: 2.3 Transverse segment of testicular tissue of 8 week-old mouse of dose group SM $(500 \mathrm{mg} / \mathrm{kg} \mathrm{B.W}$ SMB). Gray arrow: A degeneration of sperm Green arrow: Degenerated Spermatogonia cells. Orange arrow: Reduced lumen with aspermia, Black arrow: vacuolization, narrow white arrows: Desquamated cells from basal membrane Light blue arrow: Hyalinization 


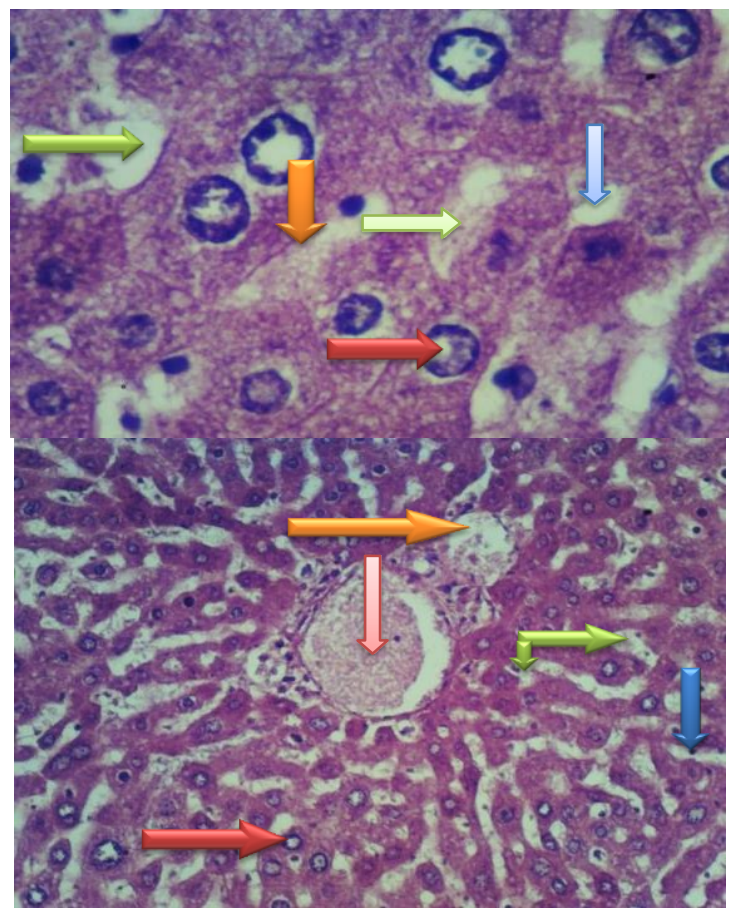

Fig: $2.4+2.5$

Fig: $(2.4,2.5)$ Sections $(H \& E x 400)$ of liver of 8 week-old mouse of experimental group treated with SM $(500 \mathrm{mg} / \mathrm{kg} \mathrm{B.W})$. Red arrow: bile duct, Green arrow: vacuolization, Light blue arrow: broad sinucidal spacing, Orange arrow: hepatic artery,

Light green: Absence of degenerated cell

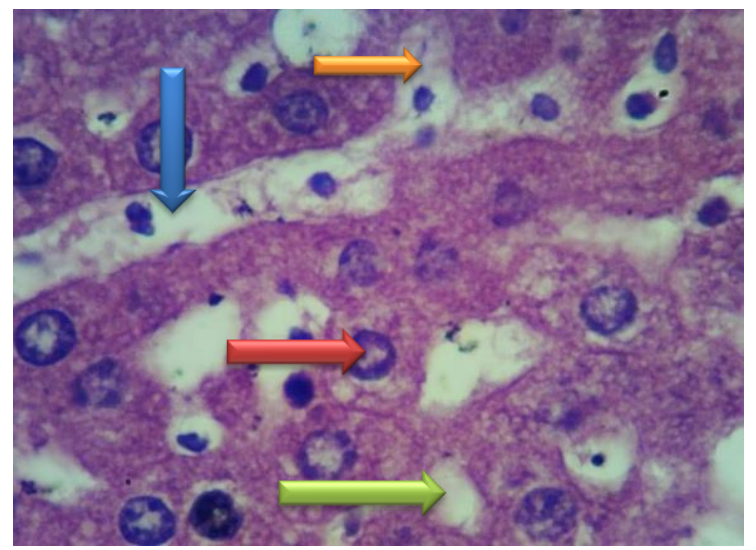

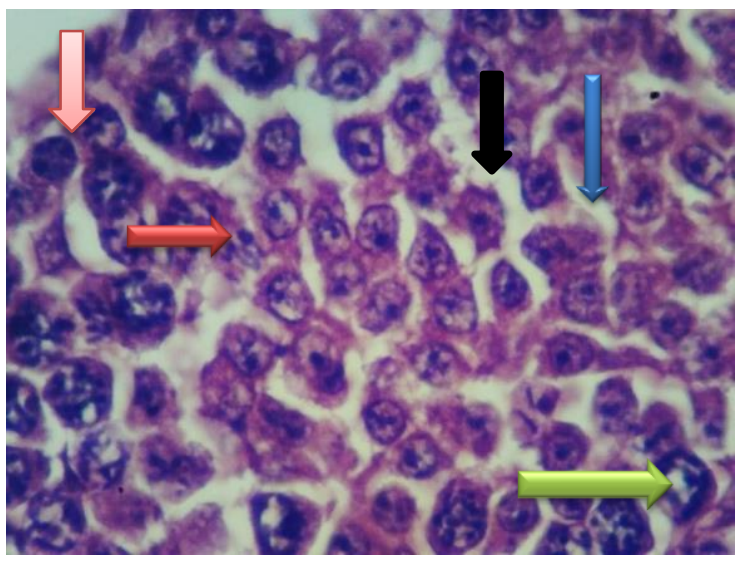

Fig 2.6

Fig 2.7

Fig: $(2.6+2.7)$ Sections $(H \& E x 400)$ of liver of 8 week-old mouse of experimental group treated with SM $(500 \mathrm{mg} / \mathrm{kg} \mathrm{B.W})$ demonstrating liver histology Red arrow: bile duct, Green arrow: vacuolization, Orange arrow: degenerative cells, Blue arrow: portal venule.

\section{DISCUSSION:}

Sulfite salts are added as additives to an assortment of nourishments in different types of food items e.g. bread rolls, chocolate, jam, brew, wine, and so forth and in prescriptions, like parenteral amino corrosive arrangements. Sulfite salts are important for various synthetics like sodium metabisulfite and sodium sulfite and are perceived as "sulfating specialists" since they discharge sulfur dioxide. Sulfites impacts poisonous impacts on the regenerative framework, the respiratory framework, and the sensory system and can likewise prompt hypersensitive responses. ${ }^{(\mathbf{1 4})}$

Sulfite is essentially scattered to all body tissues, including the central system (CNS), by being invested in the stomach. Ingested sulfite salts respond with water and make bisulfate, sulfite, and sulfur dioxide which can bring about poisonousness. (6) Digestion of the amino acids, for instance, methionine and cysteine that contain sulfur typically produce extensive endogenous proportion of sulfites in the body. Hence, human body organs are presented to sulfites both endogenously and exogenously. (16) Sodium metabisulfite lessens testosterone, a diminishing of $68 \%$. The morphometric alteration in epididymis found in the SMB treated social events might be a direct result of testosterone decline. In dose group SM seriously wreck the testicular tissues and impacts (18) spermatogenesis when contrasted with control gathering. Investigation demonstrated 


\section{International Journal of Engineering Applied Sciences and Technology, 2021 \\ Vol. 6, Issue 5, ISSN No. 2455-2143, Pages 30-38 \\ Published Online September 2021 in IJEAST (http://www.ijeast.com)}

that SM has direct harmful impact on sperms morphology in bull semen. ${ }^{(17)}$.

Testicles acquired from dose group SM $(500 \mathrm{mg} / \mathrm{kg}$ B.W) demonstrated imperfections like dim type of testicles just as wrinkles on their surfaces. These were additionally deshaped. (Fig 1.1, 1.2,1.3, 1.4,) and furthermore demonstrated deviations in the size, shape, appearance and surface of testicles and showed up not to be smooth and glossy to some reach. To the Leydig cells and Sertoli cells prompting weakened epididymis sperm development measure and decreased limit of sperms to enter oocytes. (20) The Morphometric examination demonstrated the after effect of the control and the experimental groups.

In control group testicles of mice uncover that length, width and weight of testicles stay unaffected (Fig: 1.5, 1.6, 1.7, Table: 1). in experimental group length, width and weight of testicles is hurtfully influenced and decreased size of seminiferous tubules caused the decrease in weight of testicles by SM (Fig 1.8, 1.9, 1.10 and table 2). ${ }^{(12)}$ In the current experiment the degree of testosterone revealed change in male mice because of organization of sodium metabisulfite (SMB).

Treatment of SMB to mice indicated huge decay of testosterone hormone in experimental group when contrasted with control group. SM affects regenerative capacity in grown-up male mice (Mus musculus). Showing decrease in valuable sex organ mass and repress the testicular 17 beta- 78 hydroxysteriod dehydrogenase measure likewise with the harm of gonads formative spermatogenic cells and degeneration of testosterone serum ${ }^{(\mathbf{1 3})}$ In the current consideration, the degree of glutathione depicted variety in male mice because of organization of dose. In control group glutathione level demonstrated typical reach while in experimental group it diminishes (Fig: 1.8, table: 2)

.Treatment of SM to mice indicated huge decrease of glutathione hormone in experiment group when contrasted with control group. ${ }^{(15)}$ High centralization of SM causes pressure diminishes the glutathione level in the cell. It was proposed SM change balance among union and usage of GSH (glutathione stress hormone). The high amount of SM lessens the measure of GST. ${ }^{(14)}$ In the current investigation, the degree of Malondealdehyde (MDA) announced variety in male mice because of organization of dose. In control group MDA level indicated typical reach while in experimental group it builds (Fig: 1.9, table: 2).

Treatment of SM to mice uncovered critical increase MDA level in experimental group when contrasted with control group. Histological investigation of dose group SM $(500 \mathrm{mg} / \mathrm{kg} \mathrm{B.W})$ indicated decrease in semen. Cracking of Epithelium was conspicuous in certain areas. Histological imperfections were seen as decrease of interstitial cells. In explicit sections the less number of sperms and spermatids were seen. Deteriorated connective tissue and Leydig cells were found around the tubules having the vacuoles (Fig no $2.1,2.2,2.3,2.4,2.5,2.6$, and 2.7). It also having distinctive histological blemishes like breaking of germinal epithelium, vacuolization, degenerative sperms, lumen stacked up with crushed sperm, breaking of interstitial cells and hyalinization in inside structure of testes. ${ }^{(11)}$

Current histological assessment revealed that round shape seminiferous tubules, sperm organized lumen of tubules, peritubular myoid cells, germinal epithelium and interstitial cells remains in normal condition in control group of mice. (Fig: 1.10, 2.5). ${ }^{\text {(20) }}{ }^{(16)}$ Histological investigation of dose group SM $(500 \mathrm{mg} / \mathrm{kg} \quad$ B.W $)$ Hepatic vacuolation, tremendous sinusoidal dilatation, degenerative changes and cell obstruct were showed up in liver of rodents. Association of sodium sulfite to rodents showed certifiable effects on both liver and kidney cells. Various kinds of artificial materials are used in family things, including antiperspirants, deodorizers, excellence care items, disinfectants, paints, and hair shower. ${ }^{(10)}$

\section{CONCLUSION:}

In conclusion this study provides convincing evidence that the harmful impact of sodium metabisulfite on the liver and reproductive system of male mice. Sharp decrease in the level of testosterone was formed to be key factor for studied deformation in morphology, morphometry and histology of testes. Sodium metabisulfite induced deformities were also indicated in liver tissue due to significant decrease in glutathione and increase in MDA (Malondialdehyde) level. Hence it is strongly recommended to reduce the use of sodium metabisulfite in our daily use products as its not only harmful for mice but also for man.

\section{REFERENCE}

1. Adebayo OL, Adenuga GA. (2012). Oxidative damage on the testes of adult rats 


\section{International Journal of Engineering Applied Sciences and Technology, 2021 \\ Vol. 6, Issue 5, ISSN No. 2455-2143, Pages 30-38 \\ Published Online September 2021 in IJEAST (http://www.ijeast.com)}

by sodium metabisulfite (MBS) Int J Biolog Chem Sci, 6:738-744.

2. Elmas O., Aslan M., Cağlar S., Derin N., Agar A., Alicigüzel Y, et al.(2005). The pro oxidant effect of sodium metabisulfite in rat liver and kidney. RegulToxicol Pharmacol, 42:77-82.

3. Adenuga GA., Adebayo OL. Adegbesan B. 2008. The response of liver lipid per oxidative and antioxidant defense systems of protein under nourished rats to liver regeneration. Indian J. Clin. Bio chem., 23(1):29-32.

4. Anderson P., Delgado M. (2008). Endogenous anti-inflammatory neuropeptides and pro- resolving lipid mediators: a new therapeutic approach for immune disorders. J Cell Mol Med, 12:1830-47.

5. Ifemeje J.C., Ezeonyemalu. UE. Chukwuebuka Egbuna, Olisah M.C., Ifemeje MO. (2020).Effects of Four Different Food Additives on the Oxidative Stress Markers of Wister Albino Rats. International Annals of Science, 9 (1):4651.

6. Kucukatay V., Savcioglu F., Hacioglu G., Yargiçoglu P., Agar A. (2005). Effect of sulfite on cognitive function in normal and sulfite oxidase deficient rats. NeurotoxicolTeratol, 27:47-54.

7. WistarZiqiang M. (2003). Oxidative damage of sulfur dioxide on various organs of mice: sulfur dioxide is a systemic oxidative damage agent. InhalToxicol, 15(2):181-195.

8. Woo WH, Yang H., Wong KP, Halli well B. (2003). Sulphite oxidase gene expression in human brain and in other human and rat tissues. Biochem Biophys Res Commu, 305:619-623.

9. Nair B, Elmore AR. (2003).Safety assessment of sodium sulfite, sodium bisulfate and Sodium metabisulfite. International Journal of Toxicology, 22 (2):63-88.

10. Niknahad H, O' Brien PJ. (2008). Mechanism of sulfite cytotoxicity in isolated rat

a) Hepatocytes. Chem Bio 1 Interact; 174(3):147-154. b) Noor afshan A, as a diRegulatory Toxicology and Pharmacology; 42(1):77-82

11. Ozturk N, Yargicoglu P., Derin N., Akpinar D., Agar A., Aslan M.(2011). Dosedependent effect of nutritional sulfite intake on visual evoked potentials and lipid peroxidation. NeurotoxicolTeratol, 33:244254.

12. $\mathrm{Xu}$ Han, Fe ifei Zhu Liang Chen, Hong Wu.,Tao Wang.(2020). Mechanism analysis of the Toxicity, of sodium of the

13. Yao G, Yue H., Yun Y., Sang N. (2015). Chronic $\mathrm{SO}_{2}$ inhalation above environmental standard impairs neuronal behavior and repress glutamate receptors gene expression and memory -related kinase activation via nuro inflammation in rats. Environ Res, 137(15): 85-93human hepatocytes. Molecular and cellular biochemistry, 473:2537

14. Nasiraei - Moghadam SN, Parivar K., Ahmadiani A., Movahhedin M., VaezMahdavi MR.(2014). Protective Effect of Melatonin against Inequality-Induced Damages on Testicular Tissue and Sperm Parameters. Int J Fertil Steril, 7:313-322.

15. $Y$ aroslav Pavlovskiy, Maksym Lutsyk, Antonina Yashchenko, Natalia Zaichko., John Wallace. (2018).Sulfite oxidase activity, Reduces oxidative stress and stress exposed gastric mucosa in old Rats. Proceedings of the Shevchenko Scientific Society, 54(2):33.3

16. YuCao, Hongli Liu, Ningbo Qin., Xiaomeng Ren., Beiwei Zhu, Xiaodong Xia.(2020).Impact of food additives in Mice. Trends in Food Science \& Technology, 99: 295-310.

17. Zaloga GP, Marik P. 2003. Sulfite-induced propofol oxidation: a cause for radical concern. Crit Care Med, 31(3):787-792.

18. ZhangX, Vincent AS., Halli well B., Wong KP. (2004). A mechanism of sulfite neurotoxicity: direct inhibition of glutamate dehydrogenase. The J Bio 1 Chem, 279(41):43035-43045

19. Golshan R., Karbalay-Doust S., AbdollahIfar, M.A., Rashidani - Rashidabadi A. (2013).Curcumin, the main part of turmeric, prevents learning and memory changes induced by sodium metabisulfite, a preservative agent, in rats. Exp Neuro bio 1, 22:23-30.1

20. Ziqiang M. (2003). Oxidative damage of sulfur dioxide on various organsof mice: sulfur dioxide is a systemic oxidative damage agent. InhalToxicol, 15(2): 181-195 